\title{
Tarihi Çevrede Mimari Tasarım: İstanbul Yenileme Alanları
}

\author{
Architectural Design in Historical Areas: Urban Regeneration Areas in İstanbul
}

\author{
Burcu TAN, (1) Feride Pınar ARABACIOĞLU
}

ÖZ

Türkiye'de 2005 yılında çıkarılan kentsel yenileme yasası ile yenileme alanı ilan edilen sit alanlarında ortaya konan tasarım projelerinin kültürel mirasın korunması konusunda ortaya konan evrensel ilkeler ve yasal düzenlemeleri dikkate almadığı ve bu bağlamda tarihi dokunun bütünlüğünü bozan, kimliğini değiştiren mimari tasarım çalışmaları yapıldığı gözlenmektedir. Günümüzde tarihi çevrede çağdaş mimari tasarım, koruma konusu ile birlikte ele alınmakta, konuya dair evrensel çalışmalar aracılığı ile kültürel kimliğin değerinin korunması ve gelecek nesillere aktarılması amaçlanmaktadır. Tarihi çevrede mimari tasarım konusu ile ilgili uluslararası ilkelerin tasarıma etki etmesi, yeni yapıların bağlam, süreklilik ve dönemsel okunabilirlik kavramları ısığında ortaya konması kültürel mirasın korunmasına yardımcı olacaktır. Bu doğrultuda makale İstanbul'da öncelikli olarak yenileme alanı ilan edilmiş Fener-Balat, Süleymaniye ve Tarlabaşı yenileme projelerinin evrensel koruma ve mimari tasarım ilkeleri kapsamında sorgulanmasına odaklanmaktadır. Bununla birlikte ülkemizde mimari tasarıma etki eden dış faktörlerin ortaya konması hedeflenmiştir. Makalede öncelikle tarihi çevre koruma ve tarihi çevrede mimari tasarım kavramları, tarihsel süreçte ortaya konmuş evrensel çalışmalar ve Türkiye'de bu kapsamda yapılan yasal ve kurumsal düzenlemeler üzerinden irdelenmiş, daha sonra bu kavramlar kapsamında tarihi çevrede mimari tasarım kriterleri belirlenmiştir. Çalışma alanı olarak belirlenmiş üç bölge için hazırlanmış yenileme projeleri irdelenerek tasarım sorunlarının ortaya konması amaçlanmıştır. Bu doğrultuda projeler, çalışmada belirlenen tasarım kriterleri ve Türkiye'de tasarıma etki eden dış faktörler kapsamında konunun uzmanları ile yapılan anket çalışması aracılığı ile sorgulanmıştır. Söz konusu yenileme projelerinde tasarım çalışmalarının bağlam, süreklilik, dönemsel okunabilirlik kavramları ile ele alınmadığı aynı zamanda Türkiye'nin içinde bulunduğu siyasi, ekonomik durumun tasarım çalışmalarına etki ettiği sonucuna varılmıştır.

Anahtar sözcükler: istanbul yenileme alanları; kentsel yenileme; tarihi çevre koruma; tarihi çevrede mimari tasarım.

\section{ABSTRACT}

In Turkey, it is observed that, the design projects in sites declared as protected areas with the urban regeneration law enacted in 2005, neglect the universal principles and legal regulations set forth in the protection of cultural heritage. Consequently, architectural design works distorting the integrity and changing the identity of the historical texture are commonly seen. Today, contemporary architectural design in the historical environment is handled together with the subject of conservation aiming to protect the value of cultural identity and transfer it to future generations in the light of various universal studies. Taking design principles into account which are continuously being discussed on international levels regarding new designs within the historical environment will help protect the cultural heritage by constructing the new buildings in the light of context, continuity and historical texture. In this regard, the current study focuses on the questioning of Fener-Balat, Süleymaniye and Tarlabaşı renovation projects, which were declared as regeneration areas in Istanbul, within the scope of universal protection and architectural design principles. In the study, initially, the concepts of conservation of historical environment and architectural design in the historical environment were examined through the lens of international literature and the related legal and institutional arrangements in Turkey, and then, the architectural design criteria in the historical environment were specified within the scope of these concepts. This study aims to reveal the design problems in the regeneration projects of designated three regions. To this end, the projects in question were evaluated in terms of the specified design criteria and the external factors affecting the design studies in Turkey through a survey held with experts on the field. The results reveal that context, continuity and periodical readability are neglected in the renovation projects in question and the political and economic situation in Turkey affects the design works.

Keywords: Urban regeneration areas in Istanbul; urban regeneration; conservation of historic areas; architectural design in historic environment.

Yıldız Teknik Üniversitesi Mimarlık Fakültesi, Mimarlık Bölümü, İstanbul

Başvuru tarihi: 26 Eylül 2019 - Kabul tarihi: 10 Mayıs 2020

İletişim: Burcu TAN. e-posta: burcutan2010@gmail.com

○ 2020 Yıldız Teknik Üniversitesi Mimarlık Fakültesi - @ 2020 Yıldız Technical University, Faculty of Architecture 


\section{Giriş}

Geçmişten bugüne ulaşmış, insanların sürekli değişim halinde olan değerlerinin, inançlarının, bilgilerinin ve geleneklerinin bir yansıması olarak betimlenen somut ve somut olmayan tüm varlıklar kültürel mirası tanımlamaktadır. ${ }^{1}$ Kültürel mirası oluşturan ögelerden tarihi çevreler ise içinde bulundukları kentlere, kültürel sürekliliğin ve kimliğin simgesi olarak mimari ve sosyal zenginlik katarlar. Bu bağlamda tarihi çevrelerde kültürel mirasın korunması, kentsel dokunun sürekliliğinin ve içinde yaşayan toplumların kültür birikiminin ve kimliğinin korunmasını sağlamak için gereklidir.

Çağdaş toplumlarda, tarihi çevrelerdeki süreklilik ve bütünlüğün korunması için geçmişi korumak kadar değişimin hızına uyum sağlamak, çağın gereklerini yerine getirmek ve sosyal yaşantının devamlılığını sağlamak da önem teşkil etmektedir. Bu anlamda tarihi dokunun fiziksel değişimini belirleyen mimari tasarım uygulamaları tarihi kentsel mekânın bütünlüğüne doğrudan etki etmektedir. Dolayısı ile günümüzde tarihi çevrelerde çağdaş mimari tasarım müdahaleleri gerçekleştirilirken kültürel kimliğin değerinin ve kentsel bütünlüğünün korunmasını, gelecek nesillere aktarılmasını sağlamak temel amaç olmalıdır.

Tarihi çevrede gerçekleştirilen mimari tasarım uygulamalarını, tarihi çevrede yeni yapı tasarımı, yenileme, restorasyon, ek yapı, yeniden yapım gibi pek çok sınıflama ile ele almak mümkündür. Ancak bu uygulamaların özellikle de büyük ölçekli müdahalelerde etkisinin ortaya konması, bu bağlamda da yapılan uygulamanın mimari tasarım ilkelerine uygunluğunu tartışmak gerekliliği doğmaktadır.

Makale öncelikle tarihi çevrede mimari tasarım ilkelerini tarihsel süreç içerisinde hem evrensel bildirgeler hem de ülkemiz yasal düzenlemeleri üzerinden okuyarak nedenleri ile ortaya koymayı, daha sonra da bu ilkelerin İstanbul'da "yenileme alanı" ilan edilerek üzerlerine "yenileme projeleri" üretilmiş olan üç bölgedeki varlığını anketler aracılığıyla sorgulamayı hedeflemektedir.

\section{Tarihsel Süreçte Tarihi Çevre Koruma ve Mimari Tasarım}

Koruma kaygısı, tarihin her döneminde farklı amaçlar ve nedenlerle gündeme gelmiştir. Korunacak eserlerin seçimi toplumların ekonomik, sosyal ve siyasal koşullarına ve inançlarına göre farklılık göstermiş, korunacak eserlerde yapılacak müdahalelerde ise dönemin sanatsal ve estetik anlayışının izleri seçilmiştir. ${ }^{2}$ 19. yüzyılda özellikle Avrupa'da toplumsal kimlik, kültür kavramının toplumlar içinde gelişmesi korumaya olan ilgiyi artırmış, ${ }^{3}$ tek yapı ölçeğinde koruma ile ilgili uygulamaların bilimsel yöntemle

\footnotetext{
${ }^{1}$ http://www.icomos.org.tr/Dosyalar/ICOMOSTR_tr0784192001542192602.pdf

2 Erder, 1999, s. 1.

3 Kuban, 2000, s. 48.
}

yapılan bir eylem haline dönüşmesi de bu dönemde başlamıştır. ${ }^{4}$

Avrupa'da Sanayi Devrimi sonucu kırdan kente göçen nüfus ile tarihi kent merkezlerinin yaşadığı hızlı yoğunlaşma sonucunda endüstriyel üretimin kent merkezlerinde yoğunlaşması, kentlerde hava kirliliği, sağlıksız yaşam alanları, alt yapı yetersizliği gibi sorunları da beraberinde getirmiştir. Bu nedenle de hızla tahrip olan kent merkezlerinde doğal ve yapılı çevreye karşı duyarlılık artmaya başlamıştır. ${ }^{5}$

19. yüzyılda plansız ve denetimsiz şekilde yoğunlaşan kentlerin yeniden yapılandırımasını sağlayacak planlı bir eylem olarak kentsel dönüşüm kavramı ortaya çıkmıştır. ${ }^{6}$ 19. yüzyıldan bugüne uygulanan kentsel müdahale biçimlerinde farklılıklar görülmekle birlikte, 19. yüzyılın ikinci yarısından 1945 'lere kadar, sanayileşmenin getirdiği göç sonucu kentlerdeki fiziksel ve toplumsal bozulmaya karşı kentsel yenileme en önemli müdahale biçimi olmuştur. ${ }^{7}$ Baron Haussmann'ın Paris planı bu dönemde hazırlanmış, kentin iyileştirilmesi ve kenti daha iyi kontrol etmek amacıyla mevcut dokunun yıkılarak geniş cadde ve bulvarların açılması önerilmiştir. ${ }^{8}$

İkinci Dünya Savaşı sonrasında ise varoluşçuluk akımı ile geçmişin bağlamından tümüyle uzaklaşma ve süregelmiş olan devamlılığı yok sayma eğilimi artmıştr. ${ }^{9}$ Bu dönemde mimari anlayışa hakim olan rasyonalizm akımı, sadeliği ve toplu üretime uygunluğu nedeniyle İkinci Dünya Savaşı sonrasında büyük ölçüde tahrip olmuş kentlerin yeniden inşasında da kullanılmıştr. Avrupa'da büyük kentlerinin merkezlerinde, savaşın tahrip ettiği konut alanları tamamen yıkılmış, bunların yerini yüksek katlı ofis ve ticaret yapıları almıştr. 1950-1960 yılları arasında modernizm anlayışı yeni gelişen inşaat teknikleri ile birlikte kaba bir fonksiyonalizm olarak algılanmış ve dünyaya yayılmıştı. ${ }^{10}$ Kentsel doku göz ardı edilerek bağlamdan uzak yapılar oluşturulması, mevcut tarihi dokunun bütünlüğünün hızlı bir şekilde bozulmasına ${ }^{11}$ ve koruma altına alınmamış kent merkezlerinin tahribine neden olmuş, bu durum koruma konusunda çalışmaların kapsamını değiştirmiş, kentsel koruma anlayışının ortaya çıkısını hızlandırmıştr. ${ }^{12} \mathrm{Bu}$ anlayışın devamında ise ulusal bilincin ve kültürün oluşturulması için anıtların tek başlarına değil; doğal ve yapılı çevreleriyle birlikte ve yapı grupları olarak korunmaları gerektiği görüşü ağırlık kazanmaya başlamıştı. ${ }^{13}$

Bu gelişmeler sonucunda Venedik'te 1964 yılında düzenlenen "Il. Uluslararası Tarihi Anıtlar Mimarlar ve Teknisyenleri Kongresi"nde tarihi anıt kavramının kapsamı genişletilmiş, tarihi çevre kavramı ilk kez Venedik Tüzüğü ile ortaya konmuştur. ${ }^{14}$

\footnotetext{
4 Ahunbay, 1996, s. 8.

5 Akkar,2006, s. 30.

Görgülü, 2009, s. 769

Akkar, 2006, s. 30

${ }^{10}$ Baytin, 1994, s. 24-25.

${ }^{11}$ Karakul, 2009, s. 50.

12 Dinçer, 2013, s. 25.

${ }^{13}$ Ahunbay, 1996, s. 116-119.

8 Lampugnani, 1985, s. 24.

Erder, 1999, s. 5.
} 
Venedik Tüzüğünün hemen ardından 1965 yılında mimari mirasın korunmasıyla ilgili kuram, uygulama yöntemi ve bilimsel tekniklerin geliştirilmesi alanında çalışmalar yapmak amacı ile Uluslararası Anıtlar ve Sitler Konseyi ICOMOS kurulmuştur. ${ }^{15}$

Aynı zaman diliminde tüm ülkeler koruma ile ilgili kendi yasal alt yapılarını oluşturmaya başlamışlardır. Avrupa'da bir yandan tarihsel süreçte fiziksel ekonomik ve politik nedenlerle hızlı şekilde değişen, bütünlüğü ve kimliği bozulan tarihi kent dokuları ve tarihi çevre koruma konularına, diğer yandan ise tarihi çevrelerin yeni ile bütünleşme sorununa odaklanılmaya başlanmıştır.

1970'lerin başında Avrupa Konseyi, Avrupa Mimari Mirasının korunması konusunda çalışmalar yaparak, 1975 yılını "Avrupa Mimari Miras Yılı" ilan etmiştir. ${ }^{16}$ Gerçekleştirilen kapsamlı uluslararası çalışmalar sonucunda 1975 yılında açıklanan Amsterdam Bildirgesi ile bütünleşik koruma kavramı ortaya çıkmış, ${ }^{17}$ tarihte ilk kez tarihi çevrede mimari tasarım konusu ele alınmış ve "çağdaş mimarlığın geleceğin mirasını oluşturacağı ilkesi ile yüksek kaliteli olması için çalışıımalıdır" maddesi bildirgede yer almıştr. ${ }^{18} 1976$ yılında yayınlanan Nairobi Bildirgesi'nde ise tarihi çevre ve mimari tasarım ilişkisinin nasıl olması gerektiği ortaya konmuş, tarihi çevrelerde tasarım yapılırken çevresi ile uyuma dikkat çekilmiştir. ${ }^{19}$

Bat ülkelerinde 1970 'lerde yaşanan ekonomik yavaşlama tarihi kent merkezlerinde sosyal mekansal ve ekonomik değişime neden olmuş, ortaya çıkan nüfus ve istihdam kayıpları sonucunda, bu alanlar ekonomik canlııklarını yitirmeye başlamıştır. 1960'ların sosyal yaşam odaklı kentsel dönüşüm hareketinin yetersiz kalması sonucunda 1970'li yıllarda gelişmiş ülkelerin büyük şehirlerinde yeniden canlandırma hareketi doğal süreçte ortaya çıkmıştı. 1980'lerde şehir merkezindeki düşük arsa ve konut fiyatları özel sektörün bu alanlara ilgisini arttrmış, özellikle gelişmiş ülkelerin tarihi kent merkezlerinde kamu-özel sektör ortaklığında kentsel müdahale süreci başlamıştr. ${ }^{20}$ Tarihi kent merkezlerinde çöküntü bölgeleri haline gelmiş alanlarda, ekonomik canlanmayı amaçlayan kentsel müdahale biçimlerinde özel sektörün aktörler arasında yer alması ekonomik kaygının öne çıkmasına neden olmuştur. ${ }^{21}$

Bu bağlamda tarihi kentsel alanlarda kültürel, sosyal ve hatta ekonomik kayıplar yaşanması karşısında ICOMOS, Venedik Tüzüğü’nü tamamlamak üzere, 1987 yılında tarihi kentlerin ve kentsel alanların korunmasını ele alan Washington tüzüğünü hazırlamıştr. Tüzükte tarihi çevrelerde yeni yapıların mevcut dokuya saygılı olması, ölçek ve parsel boyutu olarak uyumlu olması gerektiği savunulmuştur. ${ }^{22}$

\footnotetext{
${ }^{15}$ Madran ve Özgönül, 2005, s. $117 . \quad{ }^{19}$ Ahunbay, 1996, s. 121.

${ }^{16}$ Kaderli, 2014, s. $33 . \quad{ }^{20}$ Carmon, 1999, s. 147-148.

17 Dinçer, 2013, s. 26.

${ }^{18}$ ht t p://www. icomos.org. ${ }^{22}$ htt p: // w w w. icomos.org. tr/Dosyalar/ICOMOSTR_ tr/Dosyalar/ICOMOSTR tr0458320001536681780.pdf - tr0627604001536681570.pdf
}

2011 yılına gelindiğinde ise 17. ICOMOS genel kurulunda kabul edilen Valletta İlkelerinde tarihi çevrede mimari tasarım konusu, değişim ve yapılı çevre başlığı altında ele alınmış, mimari müdahalelerin tarihi çevre değerlerine, katmanlarına saygılı olması ve yeni mimarinin mekansal düzenle ve geleneksel biçimlenmeyle uyumlu olması gereği ortaya konmuştur. Yeni tasarımlar yapılırken kentsel dokunun ve mekânın parçalanmasından kaçınılmasına, yeni mimaride mevcut dokuyu olumsuz etkilemeyen, yerin ruhunu kavrayan ve ayırt edilebilen bir yaratıcılığa olanak tanıyan bir kompozisyon sürekliliğine öncelik verilmesine dikkat çekilmiş, tarihi çevrede tasarlanacak çağdaş mimari elemanların kentin canlılı̆ına ve sürekliliğine katkıda bulunacağı savunulmuştur. ${ }^{23}$

Tarihi sürece bakıldığında, yapılan uluslararası toplantıların dönemlerine ait kentsel sorunlara yönlendiği, sosyal ve ekonomik gelişmelerin tarihi kent kimliğine etkileri ile birlikte alınması gereken önlemlere odaklanıldığı ve çözüm üretmeyi hedeflediği görülmekle birlikte özellikle mimari tasarım ve tarihi çevre ilişkisinin bir konu olarak ele alınmasının 70'li yılların ortalarına tarihlendiği söylenebilir (Tablo 1).

Bu kapsamda 1975 tarihli Amsterdam Bildirgesi'nden günümüze kadar çağdaş koruma anlayışı ile oluşturulmuş uluslararası ilkelere bakıldığında tarihi çevrede mimari tasarım için; yere özgü, bağlama saygılı, soyut ve somut ögelere saygılı, çevresi iyi analiz edilmiş, çağdaş, mekanın sürekliliğine katkı sağlayacak, kentsel dokuyu ve mekânı parçalamayan, dönemi iyi ayırt edilebilen, kütle ve hacim olarak uyumlu, yerin ruhuna uygun tasarım kavramlarının ortaya çıktı̆ı görülmektedir.

\section{Türkiye'de Kentleşme Sürecinde Tarihi Çevre Koruma ve Mimari Tasarım}

Avrupa'da doğan ve gelişen modernite anlayışı, 1840'। yıllardan itibaren Osmanlı devletinin ekonomik ve kurumsal yapısını da etkilemeye başlamış, koruma ve kentleşme konusunda yeni kurumsal yapılanma ve yasal düzenlemeler oluşturulmuştur. ${ }^{24}$

Cumhuriyet öncesi koruma çalışmaları tek yapı ölçeğinde gerçekleştirilmiştir. Osmanlı döneminde ilk olarak 1869 yılında Asar-ı Atika Nizamnamesi hazırlanmış, sonrasında 1874, 1884, 1906 tarihli Asar-ı Atika Nizamnameleri (eski eserler tüzükleri) hazırlanmıştır. Cumhuriyetin ilanının sonrası, 1973 yılına kadar Osmanlı döneminde hazırlanan 1906 tarihli Asar-ı Atika Nizamnamesi yürürlükte kalmış tek yapı ölçeğinde koruma anlayışı sürdürülmüştür. ${ }^{25}$

Cumhuriyetin ilanı ile modernleşme sürecine giren Türkiye'de kentleşme hareketleri hız kazanmış, kentlere çağdaş nitelik kazandırılması ve sistemli bir kentleşme

\footnotetext{
${ }^{23} 20$. http://www.icomos.org.tr/Dosyalar/ICOMOSTR_ tr0592931001536912260.pdf

${ }^{24}$ Tekeli, 2009, s. 107-109. $\quad 25$ Özdemir, 2005, s. 21.
} 
Tablo 1. Tarihsel süreçte tarihi çevre koruma ve mimari tasarım ile ilgili hazırlanmış uluslararası belgeler

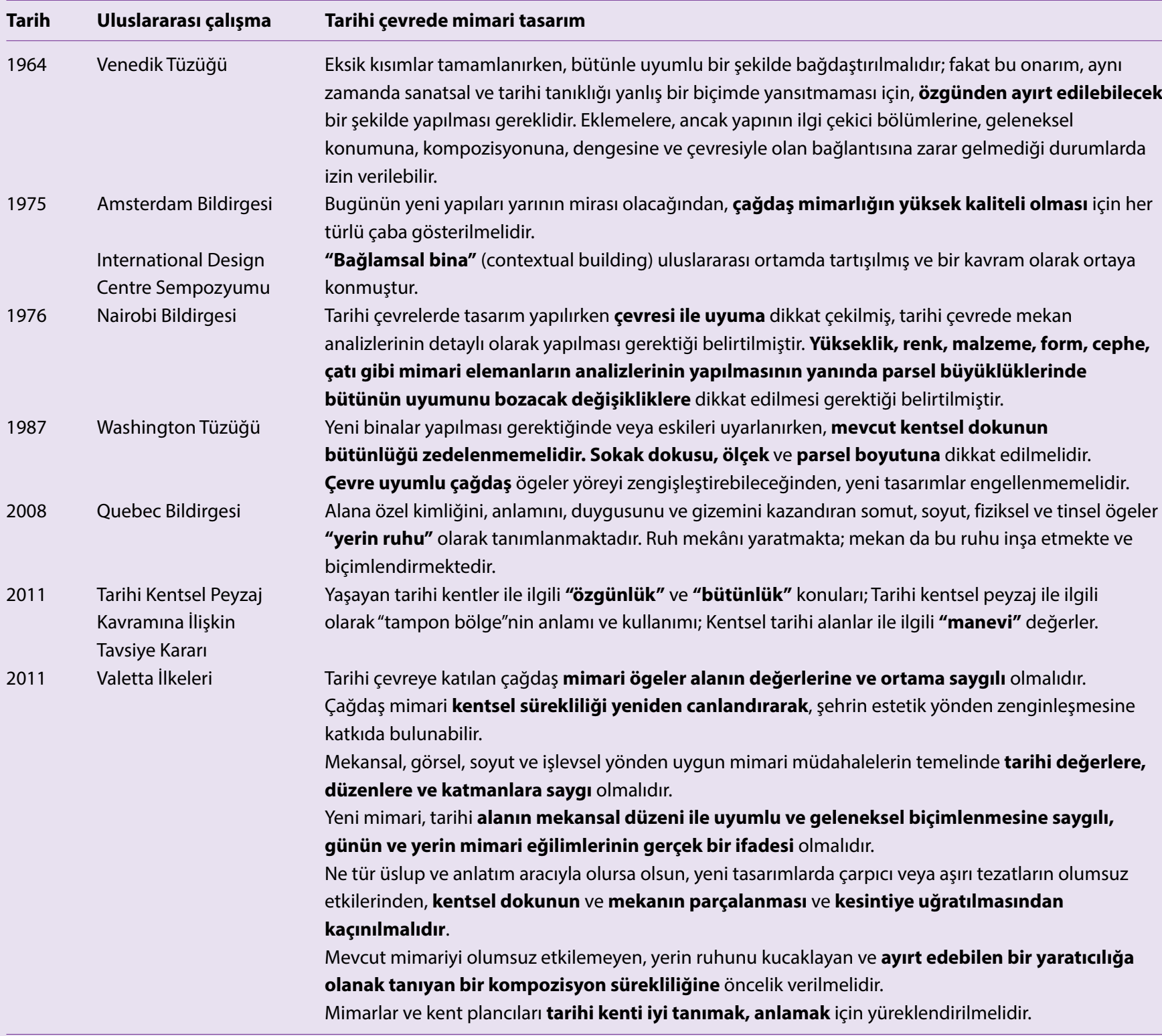

hedeflenmiş, bu hedef doğrultusunda Osmanlıdan kalan mevzuat değiştirerek 1930-1935 yılları arasında kent mekânlarını düzenlemeye yönelik yasal ve kurumsal düzenlemelere gidilmiştir. 1930 yılında 1580 sayılı Belediye Kanunu ve 1593 sayılı Umumi Hıfzıssıhha Kanunu, 1933 yılında 2290 sayılı Yapı ve Yollar Kanunu ve 2033 sayılı Belediye Bankası Kuruluş Kanunu, 1934 yılında çıkarılan 2722 sayılı Belediye İstimlak Kanunu ile 1935 yılında çıkarılan 2763 Sayılı Belediyeler İmar Heyetinin Kuruluşuna İlişkin Kanun bu dönemde çıkarılmıştır.

Bu yasalarla oluşturulan sistem Cumhuriyet dönemi kent planlaması yaklaşımını $80^{\prime}$ li yıllara kadar belirlemiş belli büyüklükteki kentlere plan zorunluluğu getirilmiștir. Batıda ortaya çıkan "güzel kent" anlayışının Türkiye'de yayılması so- nucu kentin tümü mevcut kent dokusunu dikkate almadan modernist bir yaklaşımla planlanmıştır. Bu dönemde hazırlanan planların kentlerinin dokularıyla uyum içinde bulunmaması, salt estetik kaygılarla hazırlanması, kentin ekonomisini, uygulama sorunlarını dikkate almaması eleştirilmiştir. ${ }^{26}$

İkinci Dünya Savaşı Türkiye'de de yenilikleri beraberinde getirmiş, özellikle 1950 'lerde tarımda modernizasyona yönelerek ekonomik olarak dışa açılma süreci başlamıştı. Sanayi sektörünün gelişimi ve tarımda makineleşmeye bağı olarak işgücü talebinin azalması bu sektörde çalışan işgücünün kente göçünün hızla artmasına neden olmuştur. Bu süreç kentlerin kontrolsüz bir şekilde büyüdüğü ve yoğun

\footnotetext{
${ }^{26}$ Tekeli, 2009, s. 114-116.
} 
göçe hazır olmayan kentlerde să̆lıksız şehirleşme koşullarının ortaya çıktığı dönemdir. İkinci Dünya Savaşı içinde konut yapımının duraklamış olması ve hızlı kentleşme Türkiye'deki büyük şehirlerde konut açıkları yaratmış bunun sonucunda bu trkanıklığı aşmaya yönelik olarak gecekondulaşma ve yap satçılık ortaya çıkmıştır. ${ }^{27}$ Aynı dönemde Menderes hükümeti ulaşım projelerini gerçekleştirmek amacı ile özellikle İstanbul'da büyük yıkımlar gerçekleştirmiş, tarihi kentsel doku göz ardı edilerek kentte geniş bulvarlar ve yollar açılmıştr. ${ }^{28} \mathrm{Bu}$ dönem tarihi kent merkezlerinde tarihsel ve kültürel değerlerin tahrip edilmesine, yeşil alanların yok oluşuna, sosyal altyapıların yetersiz kalmasına neden olmuştur.

1950'ler Türkiye'de, çok partili hayata geçilmesi, Avrupa ile ilişkilerin gelişmesi, yeni yasal düzen ve kurumların oluşturulması, parasal kaynaklarda artış kapsamında kültür varlıklarının koruma çalışmalarında da dönüm noktası olmuştur. ${ }^{29}$ Bu dönemde 1949 yılında Avrupa Konseyine katılan Türkiye 1954'te Avrupa Kültür Antlaşması'nı kabul etmiştir. ${ }^{30}$ Yasal düzenlemelerin ilki sayılabilecek 1951 tarihli ve 5805 sayılı "Gayrimenkul Eski Eserler ve Anıtlar Yüksek Kurulu Teşkiline ve Vazifelerine Dair Kanun" ile Gayrimenkul Eski Eserler ve Anıtlar Yüksek Kurulu kurulmuştur. Kurul eski eserlerin korunması, bakımı ve onarımı işlerinde dikkate alınacak ilkeleri ve programları belirlemek, aynı zamanda uygulanmasını izlemek ve denetlemekle yükümlü olmak üzere tanımlanmıştı. ${ }^{31} 1956$ yılında çıkarılan 6875 sayılı İmar Kanunu ile hızlı büyüyen kentlerin imar sorunlarına cevap verilmesi hedeflenmiş, yasa kapsamında 1957 yılında düzenlenen İmar Nizamnamesi koruma konusunda bazı yaklaşımlar geliştirmiş ancak koruma, dini yapılar ve anıt yapılar ile sınırlandırılmaya devam etmiş, tarihi çevre koruma konusu ele alınmamıştr. ${ }^{32}$

Türkiye'de tarihi çevre koruma ile ilgili gelişmeler Venedik Tüzüğü'nün ardından ICOMOS Türkiye Milli Komitesi'nin kurulması ile başlamıştr. 1972 yılında yürürlüğe giren 1605 sayılı İmar Kanunu, tarihi değeri olan anıtsal ve sivil mimarlık ürünlerinin yanısıra bunlar ile bütünlük teşkil eden çeşme, eski sokak ve meydancık gibi yerlerin de korunması gerektiğini belirterek korumayı bir bütün içinde ele almayı öngörmüştür. ${ }^{33} 1973$ yılında ise 67 yıldır yürürlükte olan Asar-ı Atika Nizamnamesi yerine 1710 sayllı Eski Eserler Kanunu yürürlüğe girmiştir. Bu kanun ile farklı sit alanları (sit, tarihi sit, arkeolojik sit, doğal sit) ve koruma alanı tanımı yapılmış, 1951 yılında kurulan Gayrimenkul Eski Eserler ve Anıtlar Yüksek Kurulu'na bu alanlarda koruma ilkeleri belirleme, tescil ve onarım kararı alma yetkileri verilmiş hazırlanacak imar planları üzerinde görüş verme mecburiyeti getirilmiştir. ${ }^{34}$

\footnotetext{
${ }^{27}$ Tekeli, 2009, s. 116-119.

28 Özden 2016 s. 259.

${ }^{29}$ Madran,2009, s. 13.

${ }^{30}$ Kaderli, 2014, s. 36.
}

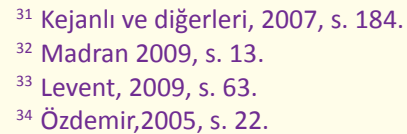

1975 yılında Amsterdam Bildirgesi koruma ilkeleri Türkiye tarafindan da benimsenmiş, UNESCO'nun 1972 yılında Paris'te gerçekleştirilen 17. Genel Konferansı kapsamında oluşturulan "Dünya Kültürel ve Doğal Mirasının Korunmasına Dair Sözleşme" 1982 tarihinde kabul edilmiştir. ${ }^{35}$ Dünyadaki gelişmeler ışığında yetersiz kalan 1710 sayılı Eski Eserler Kanunu yürürlükten kaldırılmış yerine 1983 yılında 2863 sayılı Kültür ve Tabiat Varlıklarını Koruma Kanunu çıkarılmıştır. Tek yapı ölçeğinde kültür ve tabiat varlığı kavramı dışında sit kavramı da tanımlanmış, koruma faaliyetlerinin kapsamı tek yapı ölçeğinden kentsel çevre boyutuna doğru genişletilmiştir. 2863 sayılı yasada belirtilen 'Koruma Amaçı İmar Planı' yaklaşımı ile tarihi çevre koruma konusu planlama sorunu olarak da ele alınarak koruma mevzuatinda yer almıştır. Sit alanlarında korumanın Koruma Amaçlı İmar Planıyla sağlanması öngörülmüş, önceki yasal düzenlemelerde yer almayan bütüncül ve kapsamlı bir koruma anlayışı ortaya konmuş, korumaya ilişkin karar alma yetkisi Kültür ve Tabiat Varlıklarını Koruma Yüksek Kuruluna devredilmiştir. Devam eden süreçte bölgesel koruma kurulları oluşturulmasıyla sistemin yürütülmesinde kolaylık sağlanmıştı. ${ }^{36}$ Koruma nazım planları ve müdahale projeleri, 1989 'da kurulan Kültür Bakanlığı'nın belirlediği ilke kararları ve Koruma Bölge Kurullarının onayı ile ortaya konmuştur. ${ }^{37}$

Tarihi çevre koruma ile ilgili yapılan kurumsal ve yasal düzenlemelere karşın 1980 sonrasında Türkiye, tüm dünyada yaşanan küreselleşme olgusunun etkileri altında, yeni gelişen kentleşme hareketinin bir parçası olmuştur. Özellikle İstanbul'da tarihi alanlarda yaşanan değişim süreci, 1980 sonrası ortaya çıkan ekonomik yeniden yapılanma ile oluşan toplumsal ve mekansal dinamikler çerçevesinde yeni bir biçime dönüşmeye başlamıştır. 1990'lı yıllarda büyük ölçekli, kar amacının ön planda olduğu konut projeleri ile birbiri ardına uydu kentler ortaya çıkmış ve bu alanlarda altyapısı, donatSı, ulaşımı, trafik ve park sorunu kendi içinde çözümlenmiş yerleşimler üst gelir grubu için yerleşme alanı olarak tercih edilmiştir. Bu durum kent merkezlerinde, mevcut tarihi yapılara zarar veren kullanımların artmasına, ya da bu yapıların tamamen boşaltılarak köhnemesine neden olmuştur. ${ }^{38}$

1999 yılında gerçekleşen Marmara depremi etkisi ile 2000 'li yıllarda kentsel dönüşüm kavramı siyasi olarak gündeme gelmiş, İstanbul'da devlet eli ile yeni dönüşümlerin başlamasına neden olmuştur. Bu sürece hazırlık olarak 2004 ve 2005 yıllarında yasal düzenlemeler yapılmış, bu kapsamda Büyükşehir Belediye Yasası, Belediye Yasası ve II Özel İdare Yasası değiştirilmiştir. Bu değişiklikler ile belediyelerin kentsel dönüşümle ilgili sorumlulukları tanımlanmış, belediyeler kentsel yenileme ve kentsel dönüşümün yerel kurumları haline getirilmiştir. ${ }^{39}$

\footnotetext{
${ }^{35}$ Kaderli, 2014, s. 36-37.

36 Özdemir, 2005, s. 23.

${ }^{37}$ ÇEKÜL, 2010, s. 38-39.
}

38 Özden ve Kubat, 2003, s. 82-83.

39 Özden, 2016, s. 268-270. 
Tablo 2. Tarihi çevre koruma ile ilgili uluslararası çalışmalar ve Türkiye'de yapılmış çalışmaların karşılaştırılması

\begin{tabular}{lll}
\hline Tarih & Dünya & Türkiye \\
\hline 1964 & Venedik Tüzüğü & \\
1965 & ICOMOS & \\
1967 & & ICOMOS Türkiye Milli Komitesi \\
1972 & & 1605 sayılı imar kanunu \\
1973 & & 1710 sayılı Eski Eserler Kanunu \\
1975 & Amsterdam Bildirgesi & \\
1976 & Nairobi Bildirgesi & 2863 sayılı Kültür ve Tabiat Varlıklarını Koruma Kanunu \\
1983 & & Koruma Bölge Kurullarının oluşturulması \\
& & Koruma amaçı imar planları yaklaşımı \\
1987 & Washington Tüzüğü & Kültür Bakanlığı́nın kurulması \\
1989 & & Koruma Bölge Kurularının Kültür Bakanlığına bağlanması \\
1994 & Nara Özgünlük Belgesi & \\
2004 & Valetta ilkeleri & 5226 sayılı kanun ile 2863 sayılı koruma yasasında değişiklik \\
2011 &
\end{tabular}

Ortaya çıkan koruma sorunları, eleştiriler ve Avrupa Birliği'ne uyum süreci kapsamında 2004 yılında tarihi çevre koruma konusunda var olan kurumsal yapının güçlendirilmesi ve yasal sistemin uluslararası standartlara uygun hale getirilmesi amacıyla 5226 sayılı Kanun ile 2863 sayılı Koruma Yasasında değişikliklere gidilmiştir. Bu değişiklik ile koruma politikası ortaya konmaya çalışılış ve koruma ile ilgili uluslararası belgelerde yer alan bütünleşik koruma, katılım, çevre düzenleme projesi, sürdürülebilirlik, yönetim planı, alan yönetimi kavramları ele alınmıştır. Bununla birlikte özgünlük değeri ve soyut değerler kültürel miras tanımı içinde yer almıştr. Koruma Amaçıı İmar Planı yasada tanımlanarak ve planın hazırlanma, onay ve uygulama sürecinde yaşanan sorunlar bir ölçüde giderilmeye çalışılarak, son aşamada koruma kurullarının plan onaylaması olanaklı kılınmıştı. ${ }^{40}$ Bununla birlikte korumanın uygulanabilirliğini kolaylaşttran kurumsal düzenlemeler yapılmış yerel yönetimler içinde sit alanlarındaki uygulamaları denetleyen bürolar (KUDEB) oluşturulmuştur. ${ }^{41}$

Özetle tarihi çevre koruma ve tarihi çevrede mimari tasarım konusu ile ilgili uluslararası çalışmalar Venedik tüzügünden başlayarak ülkemizde de kabul görmüş, Avrupa'da yaşanan gelişmelere paralel olarak yasal ve kurumsal düzenlemeler yapılmıştır (Tablo 2). Ancak ekonomik ve siyasal nedenler ile değişen kentleşme anlayışı sonucu tarihi çevrelerin tahribatının önüne geçilememiştir. Özellikle kentlerin ekonomik bir araç olarak görüldüğü 1980 sonrası dönemde kent merkezlerinde bulunan tarihi çevrelerde tahribatın hız kazanması ve $2000^{\prime}$ li yıllardan sonra inşaat sektörüne dayalı büyüme modeli ile tarihi çevrelerin kimli-

\footnotetext{
${ }^{40}$ Özdemir, 2005, s. 25.
}

ğine uygun olmayan ve kentsel mekanın sürekliliğine olumsuz etki eden çalışmalar yapılmıştır.

Bu bağlamda, özellikle kentsel kimliğin sürekliliğinin en önemli belirleyicilerinden olan tarihi dokuda yeni yapı şartlarının Koruma Bölge Kurullarının onayı ile yürürlüğe konan Koruma İmar Planı ile belirlendiği görülmektedir. Güncel olarak Kültür ve Tabiat Varlıklarını Koruma Bölge Kurulu tarafindan 2017 yılında düzenlenen 681 sayılı Kentsel Sitler, Koruma ve Kullanma Koşulları ile ilgili ilke Kararı'nda sit alanının doku özelliklerine uyumlu olarak yoğunluk, kütle, konum, yükseklik, mimari özellikler, yapı malzemesi, renk vb. koşulların tanımlanması gerekliliği belirtilmiştir. Bununla birlikte kentsel sitlerde bulunan tescilsiz yapılarda yeni yapılaşma şartları tanımlanmış, sit alanındaki kentsel doku bütünlüğüunü zedelemeyecek ve çevresi ile birlikte etüt edilerek hazırlanacak mimari projelerin Koruma Bölge Kurulunca uygun bulunmasından sonra uygulanabileceği belirtilmiştir. ${ }^{42}$

Ülkemizde tarihi çevrede koruma konusunda korunacak eserlere müdahale ve koruma şartları belirlenmiş olsa da tarihi çevrelerde ortaya konacak yeni yapı çalışmaları ile ilgili yasal düzenlemeye gidilmemiştir. Oysa tarihi çevrelerin bozulmasında en önde gelen etmenlerden birisi de tarihi eserlerin tahrip edilmesi ile bu çevrelerde yapılan yeni yapıların kentsel sürekliliğe olumsuz etkileri ve tarihi eserler üzerinde oluşturdukları baskılar olmuştur.

\section{Tarihi Çevrede Mimari Tasarım Ölçütleri}

Tarihsel süreçte tarihi çevre koruma konusunda ortaya konmuş tavsiye kararları, uluslararası ilkeler ve tüzükler

\footnotetext{
${ }^{42}$ https://teftis.ktb.gov.tr/TR-174602/681-nolu-ilke-karari-kentsel-sitlerkoruma-ve-kullanma-.html
} 


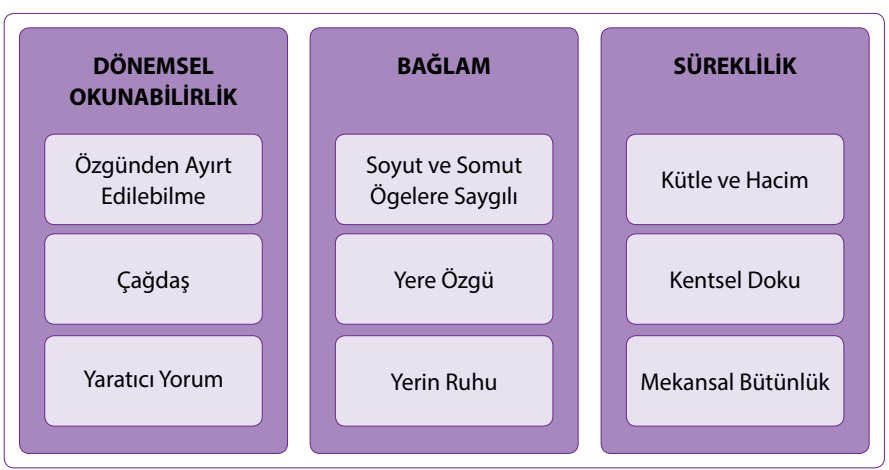

Şekil 1. Tarihi çevrede mimari tasarım kriterleri.

ve bu kararlar doğrultusunda ortaya konan tarihi çevrede mimari tasarım kavramları incelendiğinde ilgili kavramların

Tarihi çevrede;

- dönemsel okunabilirlik

- bağlam

- süreklilik

olarak üç ana başlık altında toplanabildiği görülmektedir (Şekil 1).

Tarihi dokuda yapılacak yeni müdahalenin döneminin ayırt edilmesi gerekliliği ilk olarak Venedik Tüzüğü'nde belirtilmiş, devam eden çalışmalarda özgünden ayırt edilebilme, çağdaşık, yaratıcı yorum gibi kavramlar ile desteklenmiştir. ICOMOS tarafindan hazırlanan ve uluslararası kabul görmüş Amsterdam Bildirgesi, Washington Tüzüğü ve Valetta Illkeleri'nde tarihi çevrede çağdaş mimarinin önemi vurgulanmıştır.

1975 Amsterdam bildirgesinde "Bugünün yeni yapıları yarının mirası olacağından, çağdaş mimarlığın yüksek kaliteli olması için her türlü çaba gösterilmelidir." ifadesi yer almıştr. 1987 Washington Tüzüğü ise şöyle demektedir: "Çevreyle uyumlu çağdaş ögelerin katılımı bir alanın zenginleşmesine katkıda bulunabileceğinden, engellenmemelidir."

2011 Valetta Illkeleri'nde ise çağdaş mimarinin kentsel sürekliliği yeniden canlandıracağı, şehrin estetik yönden zenginleşmesine katkıda bulunabileceği belirtilmiştir.

1975 yıından sonra bağlamsal yapı kavramı uluslararası platformda tartışılmış, süreç içinde tarihi çevrede mimari tasarımın bağlama saygılı, yere özgü olması gerektiği belirtilmiştir. ${ }^{43} 2008$ tarihli Quebec Bildirgesi'nde tarihi çevrelerde bağlamın, yalnızca fiziksel ögeler ile değil içinde barındırdığı soyut ve somut ögelerin tamamı ile ele alınması düşüncesi kapsamında "yerin ruhu" kavramı ağırlık kazanmıştr. ${ }^{44} 2011$ Valetta ilkeleri'nde "Yeni mimari, günün ve yerin mimari eğilimlerinin gerçek bir ifadesi olmalıdır ve tarihi çevreye katılan çağdaş mimari ögeler yerin ruhuna saygılı olmalıdır" ifadesi yer almıştır.

\footnotetext{
${ }^{43}$ http://www.icomos.org.tr/?Sayfa=Icomostuzukleri\&dil=tr

${ }^{44}$ https://whc.unesco.org/uploads/activities/documents/activity-646-2.pdf
}

Özer'e göre 1975 Amsterdam bildirgesinde ele alınan "Tarihi çevrede bütünleşik koruma" süreklilik kavramından ortaya çıkmıştır. ${ }^{45} 1976$ Nairobi Bildirgesi'nde tarihi çevrede fiziksel sosyal ve kültürel sürekliliğin sağlanması için mekansal bütünlük kavramına dikkat çekilmiş, kentsel dokunun bütünlüğünün çevresi ile uyumla olabileceği belirtilmiştir. Uyumun ise mimari elemanların, parsel ve yapı yüksekliğinin detaylı analizleri ile ele alınarak sağlanacağı savunulmuştur. Bu konuyla ilgili olarak Washington Tüzüğü'nde şöyle denmektedir: "Yeni binalar yapılması gerektiğinde veya eskileri uyarlanırken, ölçek ve parsel boyutuna dikkat edilmelidir". 2011 Valetta ilkelerinde ise "yeni tasarımlarda aşırı tezatların olumsuz etkilerinden, kentsel dokunun ve mekanın parçalanması ve kesintiye uğratılmasından kaçınılmalıdır" ifadesi yer almıştır. Bu bağlamda tarihi çevrelerde ortaya konacak yeni yapının çevresi ile kütle ve hacim olarak uyumlu olması kentsel dokuyu kesintiye uğratmaması ve mekansal bütünlüğün korunmasının tarihi çevrede sürekliliğinin sağlanmasına yardımcı olacağı belirtilmiştir.

Sonuç olarak günümüzde tarihi çevrelerin yeniden değerlendirilmesi kapsamında ortaya konacak olan tasarım ürününün; soyut ve somut ögeleri birlikte ele alarak yere özgü verilerin iyi analiz etmiş olması, kentsel bütünlüğü bozmaması, çağdaş olması, döneminin ayırt edilebilmesi ve tasarımcı mimarin özgün yorumuna bağlı olması görüşü evrensel olarak ağırlık kazanmaktadır (Şekil 1).

\section{Fener-Balat, Süleymaniye ve Tarlabaşı}

Türkiye'de 2000'li yıllara kadar sit alanlarında tek yapı ölçeğinde yeni yapı uygulamaları gerçekleştirilirken, 2004 sonrası kentsel yenilemenin alt yapısını oluşturmak üzere hazırlanan bir seri yasal değişim bir kırılma noktası oluşturmuştur. Koruma konusunda yaşanan olumlu gelişmelere karşın, 2005 yılında çıkarılan 5366 sayılı Yıpranan Tarihi ve Kültürel Taşınmaz Varlıkların Yenilenerek Korunması ve Yaşatılarak Kullanılması Hakkında Kanun ile sit alanı ilan edilmiş bölgelerin içinde yer alan 'bozulmuş' alanlar Bakanlar Kurulu kararı ile "yenileme alanı" ilan edilmiş ve bu alanlardaki projeler "yenileme projesi" olarak tanımlamıştır. ${ }^{46}$

Yenileme yasasının güncel koruma yasası ile bağdaşmayan yönleri tartş̧ımış, en önemli eleştiri ise yasa kapsamında yenileme alanı ilan edilen bölgelerin sit statüsünden çıkarılması ve bu alanlarda yalnızca fiziksel mekânı düzenleyen, sosyal boyutun göz ardı edildiği yenileme projelerinin oluşturulması olmuştur. ${ }^{47}$ Devam eden süreçte yenileme alanlarında yapılan uygulamalarda Koruma Bölge Kurulları yerine Yenileme Kurulları yetkilendirilmiş, sit alanlarında geçerli olan koruma imar planları koşulları etkisiz kalmıştır. Bununla birlikte fizik mekâna doğrudan etki edecek yenileme projelerinde özel bir tanımlama yapılma-

\footnotetext{
45 Özer, 1982, s. $2 . \quad$ zuatMetin/1.5.5366.pdf

${ }^{46}$ http://www.mevzuat.gov.tr/Mev- ${ }^{47}$ Dinçer,2015, s. 186-188.
} 
mış, yeni yapı tasarımı ile ilgili "imar mevzuatında öngörülen proje" tanımlanması yapılmıştır. ${ }^{48}$

Söz konusu kanun kapsamında Fatih Belediyesi sınırları içinde Fener-Balat ve Süleymaniye, Beyoğlu Belediyesi sınırları içinde ise Tarlabaşı bölgeleri öncelikli olarak yenileme alanı ilan edilen sit alanları olmuştur. 2006 yıında Tarlabaşı, Süleymaniye ve Fener-Balat yenileme alanı ilan edilmiş, 2007 yılında Tarlabaşı, 2008 yılında Süleymaniye ve 2010 yılında Fener-Balat yenileme projeleri İstanbul Yenileme Alanları Kurulu tarafindan onaylanmıştir. ${ }^{49}$ Yenileme alanı ilan edilen sit alanlarında ortaya konan mimari tasarım çaış̧maları, koruma konusuna yaklaşım biçimleri ve tarihi çevrede yeni yapı sorunsalı yine kamuoyu tarafindan en fazla tartş̧ılan konular olmuştur. ${ }^{50}$ Bu nedenle makalede güncel tarihi çevre değerlendirme çalışmalarında mimari tasarımın rolünü sorgulamak ve tarihi çevrede mimari tasarım sorunlarını ortaya koymak amacı ile 5366 sayılı Kanun ile yenileme alanı ilan edilmiş ve yenileme projeleri onaylanmış Süleymaniye, Fener-Balat ve Tarlabaşı sit alanları için hazırlanan projelerin koruma tarihi boyunca uluslararası düzenlemelerin ortaya koyduğu tarihi çevrede tasarım ölçütleri doğrultusunda irdelenmesi hedeflenmiştir.

Bu kapsamda tarihi çevre koruma, mimari tasarım ve kentsel tasarım konularının uzmanlarıyla yapılandırılmış görüşmeler gerçekleştirilmiş hem genelde hem de İstanbul özelinde tarihi çevrede mimari tasarım kavramı sit alanı statüsünden çıkarılarak yenileme projelerine konu olan projeler üzerinden sorgulanmıştır. Burada ana amaç tarihi çevre koruma ve mimari tasarım konusunda ortaya konan evrensel ilkelerin, bu ilkelere konu olan yakın dönem yenileme projelerindeki etkinliğinin sağlamasını yapmaktır.

Süleymaniye Yenileme Alanı; 24.05.2006 tarih 10501 sayılı Bakanlar Kurulu Kararınca Yenileme Alanı olarak ilan edilmiştir. 2008 yılında onaylanan projede yanarak, yıkılarak, apartmanlaşarak, depo ve imalathaneye dönüşerek neredeyse yok olan tarihi konut dokusunun yeniden canlandırılması ve bir "Osmanlı Mahallesi" yaratma fikri esas alınmıştr. Bu kapsamda proje mevcut tarihi yapıların restorasyonu, kaybolmuş tarihi yapıların rekonstrüksiyonu ve boş parseller için yeni yapı tasarımı şeklinde hazırlanmıştır. ${ }^{51}$ Hazırlanan projeler 2005 yılındaki Tarihi Yarımada 1/1000 ölçekli Koruma Amaçlı Uygulama İmar Planı'nı esas alarak hazırlanmıştır. Avan projeler tescilli yapılarda, kullanıma ve fonksiyon değişikliğine bağı bozulma yaşayan ahşap yapıların restorasyonu bunun dışında yok olmuş yapıların arşiv fotoğrafları, eski haritalardaki konumu dikkate alınarak rekonstrüksiyon projelerini içermektedir ${ }^{52}$ (Şekil 2).

\footnotetext{
${ }^{48} \mathrm{http}: / /$ www.resmigazete.gov.tr/es- ${ }^{50}$ Dinçer, 2015, s. 184

kiler/2005.12.20051214-6.htm $\quad{ }^{51}$ Dinçer, 2015, s. 199-201

${ }^{49}$ Dinçer, 2011, s. 50.
}

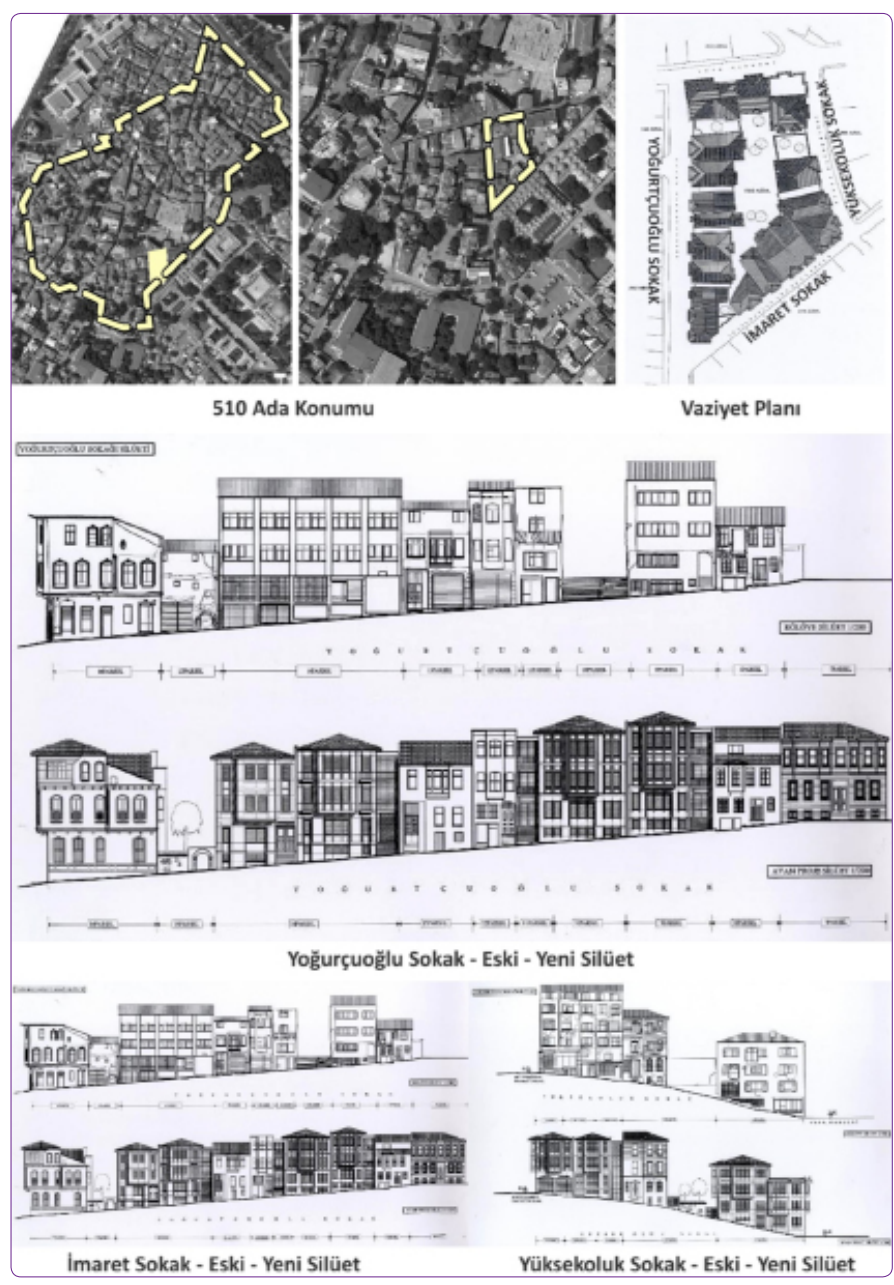

Şekil 2. Süleymaniye 1. Etap kentsel yenileme projesi çalışma alanı ve örnek ada projesi. ${ }^{53}$

Fener-Balat Yenileme Alanı; 22.04.2006 tarih, 26417 sayılı ve 23.10.2006 gün ve 26318 sayılı Resmî Gazete'de yayımlanarak yürürlüğe giren Bakanlar Kurulu kararı ile Fener-Balat Yenileme Alanı ilan edilmiş ardından 24 yapı adası ve haliç kıyısını kapsayan yenileme projesi 2010 yılında onaylanmıştı. ${ }^{54}$ Projede tüm binaların yıkılıp tescilli olan yapıların cephelerinin yeniden yapılması gerekliliği savunulmuştur. Yeni tasarımlarda mevcut cephe genişlikleri yerine birden fazla yapının birleştirmesiyle oluşturulmuş yeni yapılar yapılması gerektiği belirtilmiştir ${ }^{55}$ (Şekil 3). Alanda 'yapı adası' ölçek olarak belirlenmiş, Türkiye'nin önde gelen/isim yapmış mimarlık firmaları belirli sayılarda yapı adalarını paylaşarak tasarlamışlardır. Sahil şeridine paralel ilk ve ikinci sıradaki toplam 19 adet yapı adasını bölüşen mimarlar, bu alan ile ilgili bireysel tasarımlarını geliştirmişlerdir. ${ }^{56}$

Tarlabaşı Yenileme Alanı; 16.06.2005 tarih ve 5366 sayılı kanuna dayanarak 20.02.2006 tarih ve 2006/10172

\footnotetext{
${ }^{53}$ Fatih Belediyesi-KIPTAŞ Süleyma- ${ }^{54}$ Dinçer, 2015, s. 184.

niye Yenileme Alanı Proje Raporu, ${ }^{55}$ Dinçer, 2011, s. 58.

2008.
} 


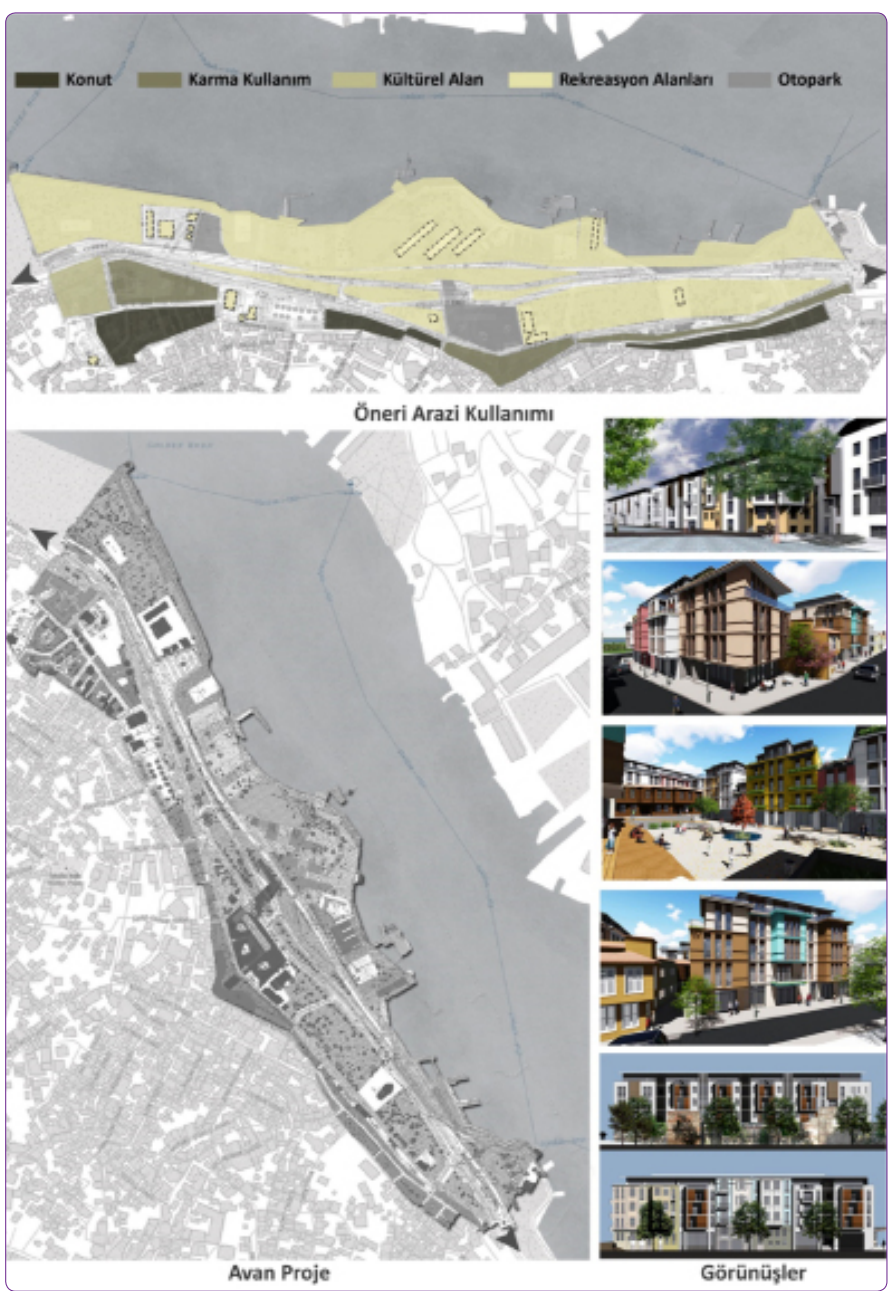

Şekil 3. Fener-Balat kentsel yenileme projesi. . $^{57,58,59}$

sayılı Bakanlar Kurulu kararı ile Yenileme Alanı ilan edilmiştir. Tarlabaşı Yenileme alanı dokuz yapı adası içinde, \%70'i tescilli, 278 binayı kapsamaktadır. Hazırlanan projede bütün yapıların tarihi değerleri tahrip olduğu kabul edilmiş, yalnızca sokak cepheleri tutularak kalan kısımları yeniden inşa edilmesi esas alınmış, yapıların derinliklerinin azalthlarak kaybedilen alanların ilave kat olarak eklenmesi tasarlanmıştır. ${ }^{60}$ Projede her yapı adası için tüm parseller birleştirilmiş, tek bir kütle olarak tasarlanmıştır, yapıların ışık ve yeşil alan ihtiyacını karşılayabilmek amacıyla adaların orta alanları iç avluya dönüştürülmüştür. Bu yöntem ile ayrıca mevcut yapıların sokak girişleri iptal edilerek ada-yapılara merkezi birkaç giriş belirlenmiş, bölgedeki güvenlik sorununa yönelik güvenlikli yaşam alanları oluşturulmaya çalışıımıştr. ${ }^{61}$ Bu kapsamda fiziksel mekanda yapılan değişikler ile sit alanındaki siluet etkisinin ve kentsel dokunun değiştirilmesini bununla birlikte tescilli

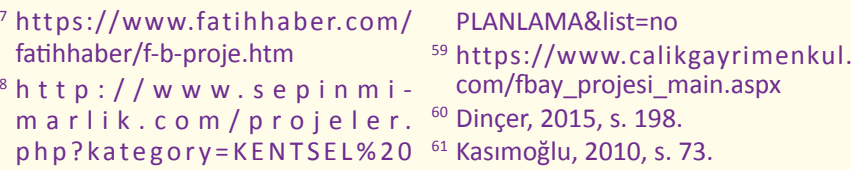

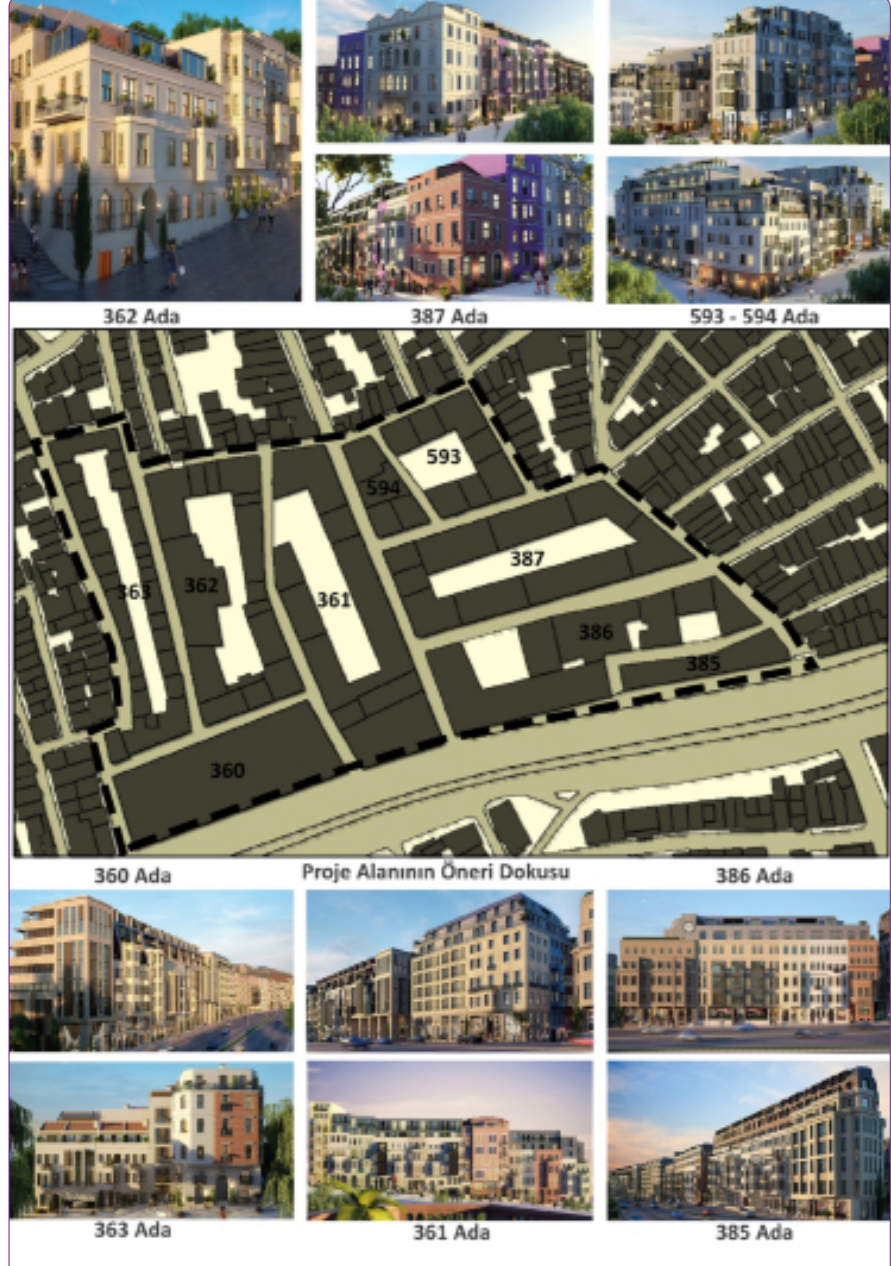

Şekil 4. Tarlabaşı kentsel yenileme projesi. ${ }^{62}$

yapıların yalnızca cephelerinin korunmasını öngörmüştür (Şekil 4).

\section{Anket Çalışması}

İstanbul'da tarihi çevre koruma, tarihi çevrelerin yeniden değerlendirilmesi ve mimari tasarım konularının uzmanları (İstanbul'daki kamu üniversitelerinin mimarlık fakültelerinin şehir planlama, mimari tasarım, restorasyon anabilim dallarında görevli akademisyenler, ilgili belediyelerde ve koruma kurullarında çalışan mimarlar ve diğer uzmanlar) belirlenerek, 255 kişilik bir evren kümesi oluşturulmuştur. Bunlar arasından 56 kişi (\%25 örneklem grubu) ile anket çalışması yapılmıştır (Şekil 5).

Anket çalışmasında ilk olarak Yenileme yasası kapsamında yenileme alanı ilan edilen sit alanları konusunda katılımcıların genel fikri sorgulanmış, katılımcıların \%66'sı 5366 sayılı Kentsel Yenileme Yasası kapsamında "Tarihi Çevrelerin" "Yenileme Alanı" ilan edilmesine olumsuz yaklaşmış sadece $\% 8^{\prime}$ i olumlu bulmuştur. Ancak ciddi bir orandaki uzmanın bu konuya çekimser yaklaşthğı da gözlemlenmektedir (Şekil 6).

${ }^{62}$ http://www.taksim360.com.tr/tr/ 


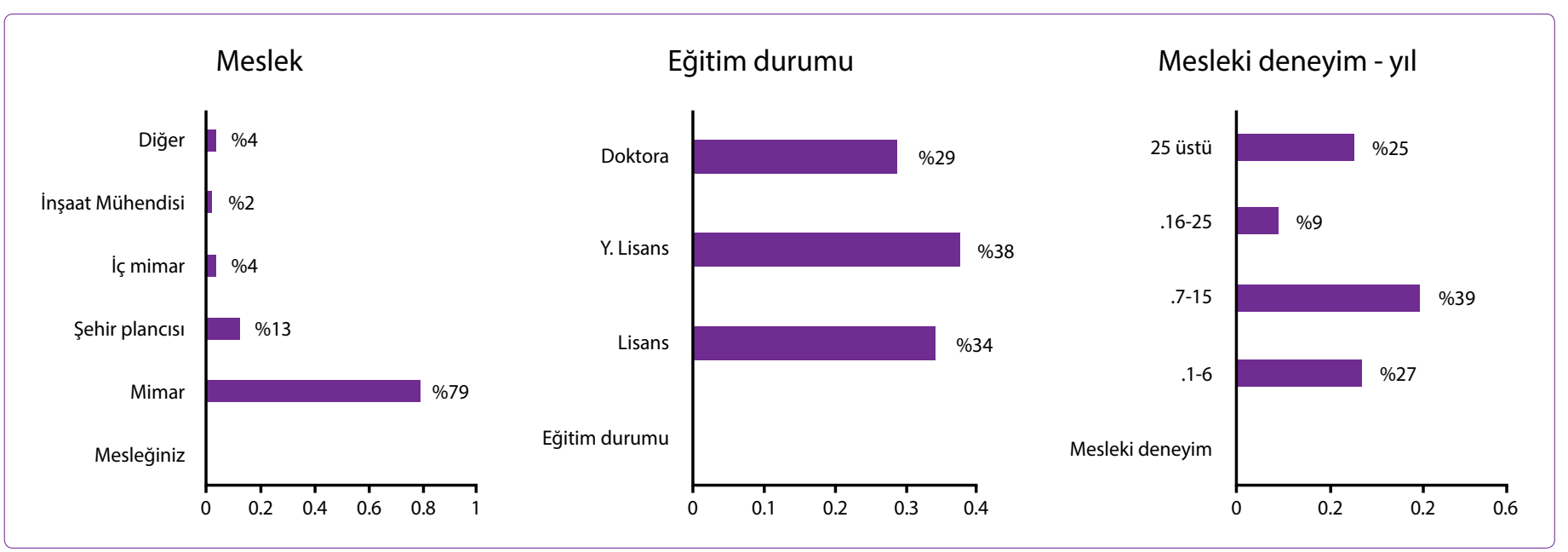

Şekil 5. Anket katılımcı profili.

Yenileme projelerinin başarısı, ele alınan üç bölge üzerinden sorgulandığında ise baskın olarak olumsuz görüş bildirildiği, özellikle Tarlabaşı ile Fener Balat bölgelerinin ortalamanın altında kaldığı görülmektedir. Özellikle Tarlabaşı kentsel yenileme projesi \%9 oranla en olumsuz proje olarak değerlendirilmiştir (Şekil 7).

Mimari tasarımın etkinliği ve başarısı sorularına verilen cevaplar değerlendirildiğinde yine her üç projede de mimari tasarımın etkin bir rol oynamadığı görüşü öne çıkmaktadır. Tüm projelerde olumsuz görüş ortalamanın üzerinde kalırken bunların arasında Tarlabaşı projesinde mimari tasarımın etkinliği ve başarısı en olumsuz olarak değerlendirilmiştir (Şekil 8).

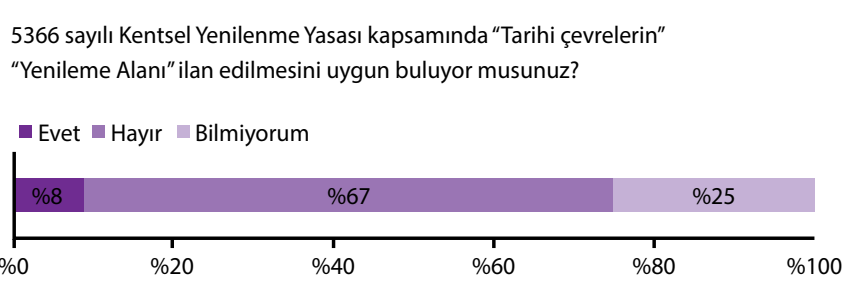

Şekil 6. "Tarihi çevrelerin" "yenileme alanı" ilan edilmesinin değerlendirilmesi.

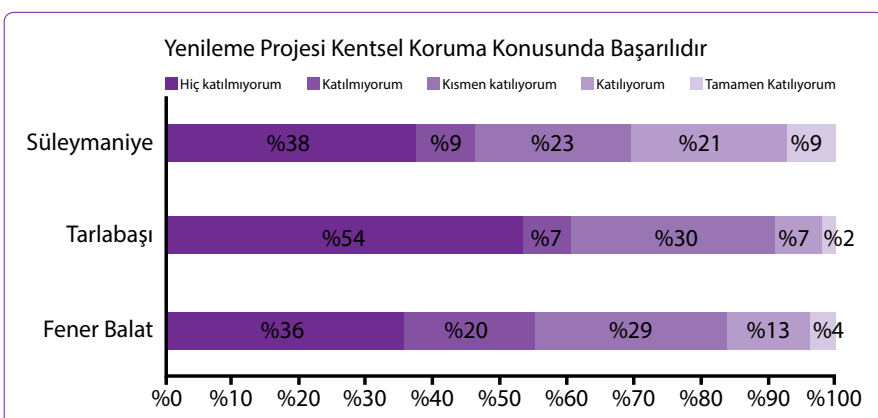

Şekil 7. Yenileme projelerinin kentsel koruma konusunda başarısının değerlendirilmesi.
Literatür taramasında ön plana çıkan üç ana kavram olan dönemsel okunabilirlik, bağlam, süreklilik kapsamında değerlendirilmesi anket çalışmasının ana yapı taşlarından birini oluşturmaktadır. Ilgili sorulardan dönemsel ayırt edilebilirlik başlığında katlımcıların toplamda \%47'sinin Tarlabaşı'nda yapılan mimari tasarım çalışmalarının döneminin ayırt edildiğini belirttiği, bu oranın Fener-Balat'ta $\% 39$, Süleymaniye'de ise \%32 de kaldığı gözlemlenmektedir. Önceki sorularda özellikle olumsuz bir proje olarak değerlendirilen Tarlabaşı projesinde dönem ayırımının yapılabildiği görüşünün hakim olduğu ortaya çıkmaktadır (Şekil 9).

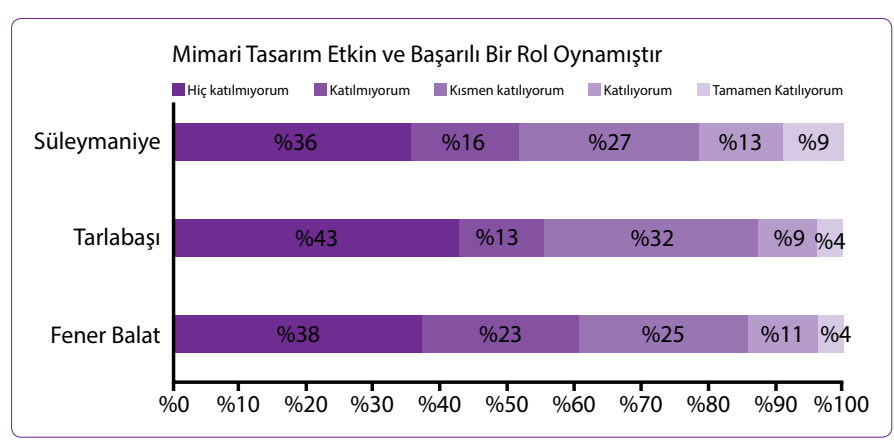

Şekil 8. Yenileme projelerinin mimari tasarımın etkinliği kapsamında değerlendirilmesi.

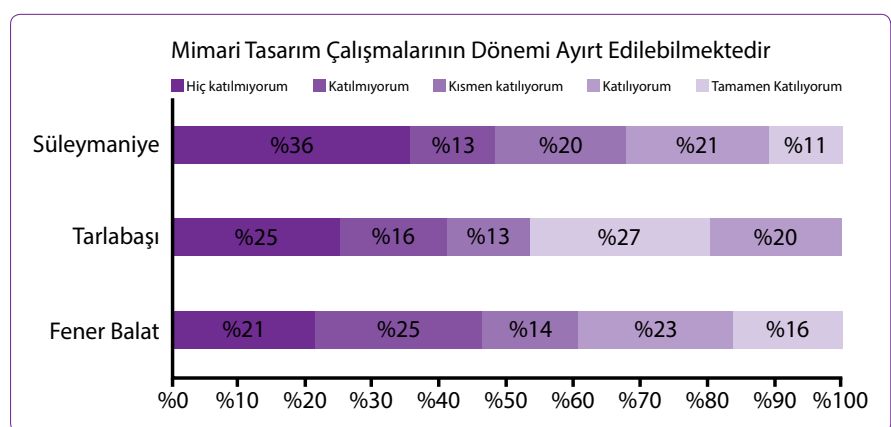

Şekil 9. Yenileme projelerinin dönemsel okunabilirlik kapsamında değerlendirilmesi. 
Katılımcılar, genel olarak seçilen projelerde mimari tasarım çalışmalarının yere özgü olmadığını belirtmiştir. Üç proje arasında kıyaslama yapııdığında Tarlabaşı kentsel yenileme projesi yere özgü tasarımlar geliştirilmesi konusunda en olumsuz proje olarak değerlendirilmiştir (Şekil 10).

"Mimari tasarım mevcut dokunun sürekliliğine katkı sağlamış mıdır?" sorusuna bakıldığında ise irdelenen projelerin tamamı için verilen yanıtların çoğunluğu olumsuz olup, katılımcıların yalnızca \%12'si Tarlabaşı, \%25'i Fener-Balat ve $\% 29$ 'u Süleymaniye kentsel yenileme projesinin kentsel dokunun sürekliliğine katkı sağladığını savunmuştur. Süleymaniye Bölgesi için ifade edilen olumsuz görüşün diğer iki bölgeden daha düşük oranda kaldığı gözlemlenmiştir (Şekil 11).

Anket çalışmasında, belirlenen projelerde ortaya konmuş mimari tasarım çalışmalarında tasarımcı mimarın yaratım sürecini etkileyen dış faktörlerin sorgulanmasına dair üç ana başlık altında katılımcılara sorular yönlendirilmiş, ülkemizde mevcut ekonomik anlayışın, siyasi anlayışın ve yasal düzenlemelerdeki eksikliklerin mimari tasarıma etkisi değerlendirilmiştir.

"Politik yaklaşımlar mimari tasarım çalışmalarını etkilemiş midir?" sorusuna katılımcılar her üç proje içinde $\% 65$ üstü oranla olumlu yanıt vermiş, projelerin tamamında siyasi anlayışın güncel değerlendirme çalışmalarında etkili olduğunu savunmuşlardır. Burada yine en yüksek oranla Tarlabaşı Projesi öne çıkmıştır (Şekil 12).

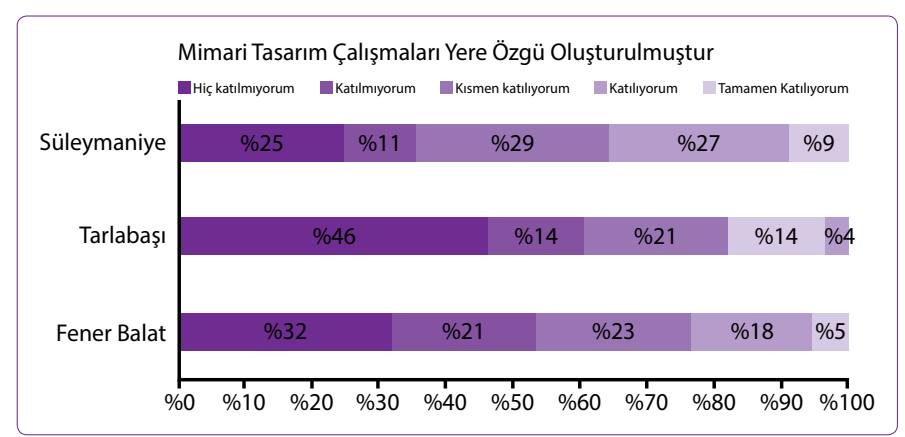

Şekil 10. Yenileme projelerinin bağlam kavramı kapsamında değerlendirilmesi.

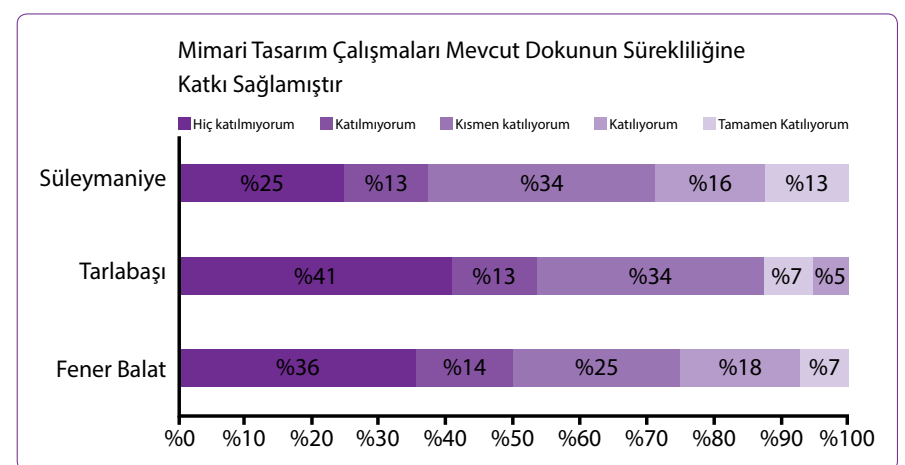

Şekil 11. Yenileme projelerinin süreklilik kavramı kapsamında değerlendirilmesi.
Ülkemizde "Ekonomik yaklaşımlar projelerde ortaya konan mimari tasarım çalışmalarını etkilemiş midir" sorusuna ise her üç proje için \%50 üzeri oranla, olumlu yanıt verilmiş, \%53 ortalama ile ekonomik yaklaşımların etkili olduğu görüşü hakim olmuştur (Şekil 13). Dağılımların politik yaklaşımlar başlığında olduğu kadar dramatik olmadığı gözlemlenmektedir.

Yasal düzenlemelerdeki eksiklikler mimari tasarımı etkilemiştir ifadesine ise diğer dış faktörlere göre katılım en düşük oranda kalmıştır (Şekil 14).

Tasarımı etkileyen faktörler karşılaştrıldığında politik yaklaşımların en etkili faktör olduğu bunu ekonomik yaklaşımların ve yasal düzenlemelerin takip ettiği görülmekte-

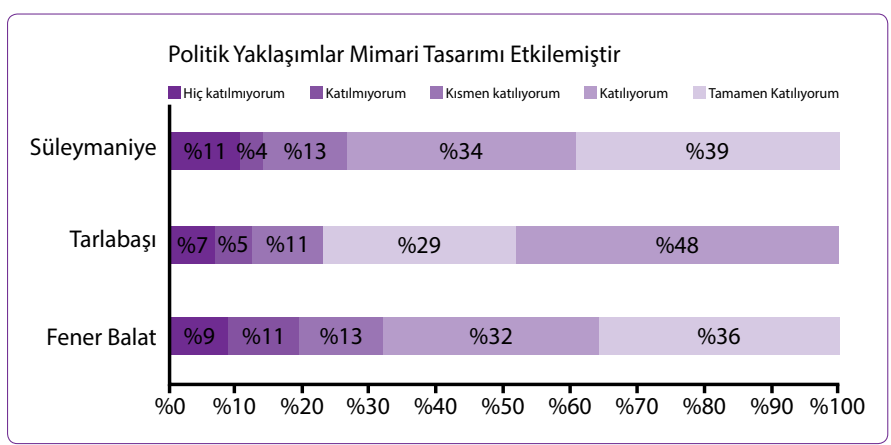

Şekil 12. Politik yaklaşımların yenileme projelerine etkisinin değerlendirilmesi.

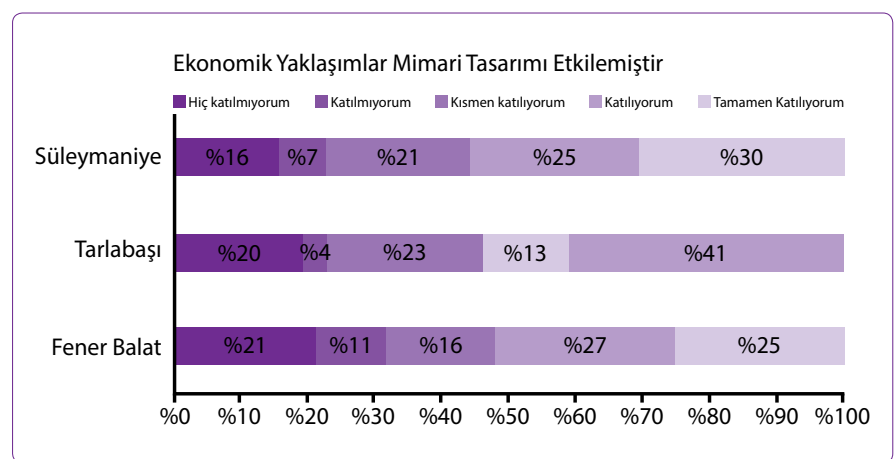

Şekil 13. Ekonomik yaklaşımların yenileme projelerine etkisinin değerlendirilmesi.

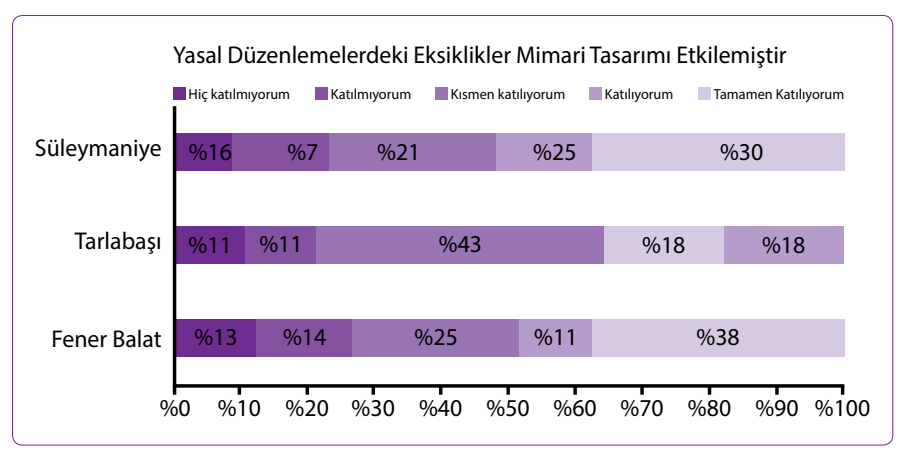

Şekil 14. Yasal düzenlemelerin yenileme projelerine etkisinin değerlendirilmesi. 
dir. Özellikle Tarlabaşı'nda politik ve ekonomik yaklaşımlar önem kazanırken yasal düzenlemelerin mimari tasarıma etkisinin diğer projelere göre daha düşük oranda kaldığı gözlenmektedir.

\section{Sonuç}

20. yüzyılda ortaya çıkan tarihi çevre koruma kavramına ek olarak yüzyılın ikinci yarısından itibaren kentleşme, bütüncül koruma, tarihi çevrede yapılacak tasarımlarda mimari tasarımın etkisi gibi konuların ön plana çıktığı görülmektedir. Hem dünyadaki gelişmeler hem de bunların ülkemizdeki yansımaları ve yasal düzenlemeler analiz edildiğinde üç ana başlığın ortaya konulduğu, kriterlerin de bu ana başıklar çevresinde geliştiği söylenebilir. Tarihi çevrenin son katmanını oluşturan yeni mimari tasarım çalışmalarının yere özgü yapılması, yapılan tasarımların döneminin ayırt edilmesi ve kentsel mekanda sürekliliği bozmaması ortak endişeler ve kriterler olarak ortaya konmuştur.

Ancak bu evrensel ölçütlerin ülkemizdeki karşılıkları okunduğunda içinde bulunduğumuz ekonomik ve politik atmosfere ve dünyadaki genel eğilime bağlı olarak oluşan neoliberal kent politikalarının etkisi sonucu, tarihi kent merkezleri üzerinde oluşan baskıların artarak sürdüğü görülmektedir. 1980 sonrası dönemde kent merkezlerinde bulunan tarihi çevrelerde tahribat "gelişme politikaları"na bağlı olarak artarak devam etmiştir. 2000'li yıllarda kentsel dönüşüm kavramının ülkemizde gündeme gelmesiyle birlikte kentsel dönüşüme konu edilmesi yasal olarak mümkün olmaması gereken tarihi alanların da kanunlarla bu kapsama alınması sonucunda Sit alanı sınırlarında "yenileme alanları" belirlenmiş ve bu alanlarda yasal olarak "Yenileme Projeleri" hazırlanmıştır.

Bu bağlamda İstanbul'da Fener-Balat, Süleymaniye ve Tarlabaşı için hazırlanmış olan "yenileme projeleri"nin tarihsel süreç içerisinde kararlar, kanunlar ve düzenlemelerle ortaya konan evrensel mimari tasarım ilkelerine uygunluğu tartışılmıştır. Konunun uzmanları ile yapılan görüşmeler söz konusu yenileme projeleri için ortaya konan tasarım çalışmalarının döneminin ayırt edilmediğini, tasarımların kentsel mekanı parçaladığını ve yere özgü tasarımların ortaya konmadığını ortaya koymaktadır.

Özellikle Tarlabaşı Yenileme Projesi, yere özgü tasarım ve kentsel mekanda süreklilik sağlama konusunda en olumsuz proje olarak değerlendirilmiştir. Bu bağlamda koruma amaçlı imar planlarına uygun olarak ortaya konan Süleymaniye Yenileme Projesi daha başarılı bulunmuş olmasına karşın ortaya konan mimari tasarım çalışmalarının dönemini yansıtmadığı belirtilmiştir.

Mimari tasarımı etkileyen faktörlerle ilgili yanıtlar incelendiğinde genel olarak yeniden değerlendirme çalışmalarının mevcut siyasi anlayış çerçevesinde şekillendiği belirtilmiş, her proje için bu durumun varlığı büyük çoğunluk tarafindan onaylanmış, özellikle Tarlabaşı projesi için bu oran en yüksek seviyeye ulaşmıştr. Sonuç olarak her üç faktörün de etkisi olmakla birlikte tarihi çevre yeniden değerlendirme çalışmalarında ortaya konan mimari tasarım projelerinin en çok güncel siyasi anlayış çerçevesinde şekillendiği savunulmuş, bu durum sorunların ana kaynağı olarak ele alınmıştir.

Türkiye'de tarihi çevre koruma konusunda uluslararası gelişmeler her dönem takip edilmiş, koruma ile ilgili yasal ve kurumsal düzenlemeler yapılmış olduğu ve yasaların bu yenileme projelerinin hazırlanmasında mimari tasarım ilkelerinin uygulanması önünde engel olmadığı görülmektedir. Ancak geçmişten günümüze her dönemde güncel siyasi ve ekonomik anlayışın, ülkemizde yeniden ele alınan tüm tarihi çevreler gibi, bu çalışmaya konu olan alanlar ve projeler üzerinde de etkili olduğu gözlemlenmektedir. Söz konusu etkenler tarihi çevre koruma ve tarihi çevrede mimari tasarım ilkelerinin önüne geçmekte, yapılan projeler konunun uzmanları tarafindan değerlendirildiğinde olumsuz sonuçlar ortaya çıkmaktadır. Üstelik benzer dönemlerde gerçekleştirilen projelerde farklı olumsuzlukların tespit edilmesi, genel geçer bir ilkeler zincirinin benimsenmediği savını da güçlendirmektedir. Günümüzde tarihi çevrede tasarım bağlamında ortaya konan evrensel eğilimler mimari tasarımı - her ne kadar somut bir reçeteye sahip olmasa da - literatür incelemesinde ortaya konan kavramlar çerçevesinde ele almayı zorunlu hale getirmektedir.

\section{Kaynaklar}

Ahunbay, Z. (1996) Tarihi Çevre Koruma ve Restorasyon, İstanbul, YEM Yayınları.

Akkar, Z. (2006) "Kentsel Dönüşüm Üzerine Batt'daki Kavramlar, Tanımlar, Süreçler ve Türkiye", Planlama Dergisi, Sayı 2, s.2938.

Balcan, C. (2012) "Kentsel Yenileme ve İi Şehir Hikâyesi: Tarlabaşı - Süleymaniye, Yüksek Lisans Tezi, Mimar Sinan Güzel Sanatlar Üniversitesi, Fen Bilimleri Entitüsü Kentsel Koruma ve Yenileme Programı.

Baytin, Ç. (1994) "Tarihi Çevrelerde Yeni Yapı Olgusuna Bir Yaklaşım, İstanbul Örneğinde Bir Uygulama Modeli", Doktora Tezi, İstanbul Teknik Üniversitesi, Fen Bilimleri Enstitüsü, Mimarlık/Bina Bilgisi Programı.

Carmon, N. (1999) "Three Generations Of Urban Renewal Policies: Analysis And Policy İmplications", Geoforum, Volume: 30(2), s.145-158.

ÇEKÜL, (2010) Yerelden Ulusala Ulusaldan Evrensele Koruma Bilincinin Gelişim Süreci, ÇEKÜL Vakfi yayınları.

Dinçer, i. (2015) “Tarihi Mekanların Yenileme Yasası ve Yenileme Projeleriyle İmtihanı", Ed.: Emre Yalçın Neoliberal Kent Politikaları ve FENER-BALAT-AYVANSARAY Bir Koruma Mücadelesinin Öyküsü, İstanbul, Türkiye İş Bankası Kültür Yayınları, s. 183-22.

Dinçer, İ. (2013) “Kentleri Dönüştürürken Korumayı Ve Yenilemeyi Birlikte Düşünmek: Tarihi Kentsel Peyzaj Kavramının Sunduğu Olanaklar" International Journal of Architecture and Planning, Volume 1, Issue 1, s.22-40. 
Dinçer, İ. (2011) "The Impact Of Neoliberal Policies On Historic Urban Space: Areas Of Urban Renewal In Istanbul", International Planning Studies, Sayı 16: 1, s. 43-60.

Dinçer, İ. (2010)"The Dilemma Of Cultural Heritage-Urban Renewal: Istanbul, Süleymaniye And Fener-Balat", 14th IPHS Conference: Urban Transformation: Controversies, Contrasts And Challenges, 12-15 July 2010 Istanbul.

Dinler, M., Güçhan, N. (2016) “Fener Ve Balat'ın Dönüşümü Üzerine: Üç Vizyon / Üç Dönem / Üç Ayrı "Koruma” Anlayışı", TUBA-KED, Sayı 14, s.225-247.

Erder, C. (1999) Tarihi Çevre Kaygısı, Ortadoğu Teknik Üniversitesi, Ankara.

Fatih Belediyesi-KIPTAŞ (2008) Süleymaniye Yenileme Alanı Proje Raporu, T.C. Fatih Belediye Başkanlığı İmar ve Şehircilik Müdürlüğü.

Görgülü, Z. (2009) "Kentsel Dönüşüm ve Ülkemiz", TMMOB İzmir Kent Sempozyumu, 8-10 Ocak 2009, s.767-780.

Kaderli, L. (2014) "Kültürel Miras Koruma Yaklaşımlarının Tarihsel Gelişimi”, Türkiye Bilimler Akademisi Kültür Envanteri Dergisi, Sayı 12, s.29-41.

Karakul, Ö. (2009) “Değişim, Süreklilik, Uyum Üçgeninde Tarihi Çevrede Yeni Yapı, Tarihi Çevrede Koruma: Yaklaşımlar Uygulamalar", Dosya Dergisi, Sayı 14, s.50-58.

Kasımoğlu, U. (2010) Kentsel Yenileme Uygulamalarının Çeşitli Boyutları İle İrdelenmesi ve Tarlabaşı Kentsel Yenileme Projesi Örneği, Yüksek Lisans Tezi, İstanbul Teknik Üniversitesi Fen Bilimleri Enstitüsü Sehir Planlama Yüksek Lisans Programı.

Kejanlı, D.T. ve diğerleri. (2007) "Türkiye'de Koruma Yasalarının Tarihsel Gelişimi Üzerine Bir İnceleme”, Elektronik Sosyal Bilimler Dergisi, Cilt 6, Sayı 19.

Kuban, D. (2000) Tarihi Çevre Korumanın Mimarlık Boyutu, İstanbul, YEM Yayınları.

Lampugnani, V.M. (1985) Architecture and City Planning in the Twentieth Century, Newyork, Published by Van Nostrand Reinhold.

Levent, Y. (2009) "Tarihi Çevre Koruma Mevzuatına Genel Bir Bakış, Tarihi Çevrede Koruma: Yaklaşımlar Uygulamalar", Dosya Dergisi, Sayı 14, s. 62-68.

Madran, E. (2009) "Tarihi Çevrenin Tarihi: Osmanlıdan Günümüze Tarihi Çevre: Tavırlar-Düzenlemeler", Dosya Dergisi, Sayı 14:1, s. 6-15.

Madran, E. Özgönül, N. (2005) Kültürel Ve Doğal Değerlerin Korunması, Ankara, TMMOB Mimarlar Odası Yayınları.
Özdemir, M. (2005) “Türkiye'de Kültürel Mirasın Korunmasına Kısa Bir Bakış", Planlama Dergisi, Sayı 1, s.20-25.

Özden, P.P. (2016) Kentsel Yenileme Yasal Yönetsel Boyut Planlama ve Uygulama, Ankara, İmge Kitapevi Yayınları.

Özden, P.P., Kubat, A.S. (2003) "Türkiye'de Şehir Yenilemenin Uygulanabilirliği Üzerinde Düşünceler", iTÜ Dergisi, Cilt 2, Sayı 1, s. 77-88.

Özer, F. (1982) Çağdaş Mimari Dizaynlamada Tarihsel Sürekliliğin Değerlendirilmesi, İstanbul, iтü Yayınları.

Tekeli, İ. (2009) Modernizm, Modernite ve Türkiye'nin Kent Planlama Tarihi, İstanbul, Tarih Vakfi Yurt Yayınları.

\section{Internet Kaynakları}

http://www.icomos.org.tr/Dosyalar/ICOMOSTR tr0784192001542192602.pdf (Erişim tarihi 17 Kasım 2018)

http://www.icomos.org.tr/Dosyalar/ICOMOSTR_ tr0243603001536681730.pdf (Erişim tarihi 17 Kasım 2018)

http://www.icomos.org.tr/Dosyalar/ICOMOSTR_ tr0458320001536681780.pdf (Erişim tarihi 17 Kasım 2018)

http://www.icomos.org.tr/Dosyalar/ICOMOSTR_ tr0627604001536681570.pdf (Erişim tarihi 17 Kasım 2018)

http://www.icomos.org.tr/Dosyalar/ICOMOSTR_ tr0592931001536912260.pdf (Erişim tarihi 17 Kasım 2018)

https://teftis.ktb.gov.tr/TR-174602/681-nolu-ilke-karari-kentselsitler-koruma-ve-kullanma-.html (Erişim tarihi 21 Aralık 2018)

http://www.icomos.org.tr/?Sayfa=Icomostuzukleri\&dil=tr (Erişim tarihi 9 Eylül 2019)

https://whc.unesco.org/uploads/activities/documents/activity-646-2.pdf

(Erişim tarihi 9 Eylül 2019)

http://www.mevzuat.gov.tr/MevzuatMetin/1.5.5366.pdf (Erişim tarihi 14 Ocak 2019)

http://www.resmigazete.gov.tr/eskiler/2005/12/20051214-6. htm (Erişim tarihi 14 Ocak 2019)

https://www.fatihhaber.com/fatihhaber/f-b-proje.htm (Erişim tarihi 9 Eylül 2019)

h t t p : / / w w w. se pin m i marlik. com / p rojeler. php?kategory=KENTSEL\%20PLANLAMA\&Ist=no (Erişim tarihi 9 Eylül 2019)

https://www.calikgayrimenkul.com/fbay_projesi_main.aspx (Erişim tarihi 9 Eylül 2019)

http://www.taksim360.com.tr/tr/ (Erişim tarihi 9 Eylül 2019) 